\title{
Successful treatment of ligneous conjunctivitis with topical fresh frozen plasma in an infant
}

\section{Sucesso do tratamento da conjuntivite lenhosa com uso tópico de plasma fresco congelado em uma criança}

\author{
Zuhal Özen Tunay ${ }^{1}$, Özdemir Özdemir ${ }^{1}$, Damla Acar ${ }^{1}$, Ece gül² ${ }^{2}$ Serap AkbaY ${ }^{3}$
}

\begin{abstract}
A 6-month-old female infant presented to our clinic with bilateral eyelid swelling, yellowish-white membranes under both lids, and mucoid ocular discharge. Her aunt had similar ocular problems that were undiagnosed. The conjunctival membranes were excised and histopathological investigation of these membranes showed ligneous conjunctivitis. Further, laboratory examination revealed plasminogen deficiency. A good response was observed to topical fresh frozen plasma (FFP) treatment without systemic therapy, and the membranes did not recur during the treatment. Topical FFP treatment may facilitate rapid rehabilitation and prevent recurrence in patients with ligneous conjunctivitis.
\end{abstract}

Keywords: Ligneous conjunctivitis; Plasminogen deficiency; Fresh frozen plasma

\section{RESUMO}

Uma criança feminina com seis meses de idade se apresentou à nossa clínica com edema palpebral bilateral, membranas brancas amareladas sob as pálpebras de ambos os olhos e descarga mucosa. Sua tia já havia apresentado problemas oculares semelhantes que não foram diagnosticados. As membranas conjuntivais foram excisadas e a investigação histopatológica das membranas demonstraram conjuntivite lenhosa. O diagnóstico de deficiência de plasminogênio foi obtido a partir de um exame laboratorial. Tratamento tópico com plasma fresco congelado (FFP) sem qualquer terapia sistêmica mostrou boa resposta. Não foram observadas recorrências das membranas. O tratamento tópico com FFP pode ajudar a reabilitação rápida e prevenir a recorrência em pacientes com conjuntivite lenhosa.

Descritores: Conjuntivite/terapia; Plasminogênio/análise; Administração tópica; Relatos de casos

\section{INTRODUCTION}

Ligneous conjunctivitis is a recurrent, rare form of chronic bilateral conjunctivitis characterized by the development of fibrin-rich, firm, wood-like pseudomembranous lesions, particularly on the tarsal conjunctiva. Plasminogen deficiency is a common cause of ligneous conjunctivitis ${ }^{(1-4)}$; this deficiency can affect not only the conjunctiva but also the other mucous membranes of the body. such as those of the oral mucosa, nasopharynx, trachea, female genital tract, and duodenum. Congenital hydrocephaly may develop in some patients with plasminogen deficiency ${ }^{(5)}$.

The management of ligneous conjunctivitis is difficult because of a lack of both therapeutic products and recommendations for appropriate substitution therapy. Several therapeutic modalities have been reported for the treatment of ligneous conjunctivitis and prevention of recurrences. However, no consensus has been gained on the treatment regimen ${ }^{(1,3)}$. The efficacy of topically applied fresh frozen plasma (FFP) together with subconjunctival FFP has been previously demonstrated in a patient with ligneous conjunctivitis ${ }^{(6)}$.

To the best of our knowledge, this study is the first to demonstrate the efficacy of topical FFP treatment alone without either subconjunctival application or systemic therapy in an infant with ligneous conjunctivitis.

\section{CASE REPORT}

In this report, all experiments were performed in accordance with the Declaration of Helsinki and with the approval of Institutional
Review Board. Informed consent was obtained from the patient's parents.

A 6-month-old female infant presented to our clinic with a 4-month history of bilateral eyelid swelling, yellowish-white membranes under both lids, and mucoid ocular discharge (Figure 1). No other pathology was detected in the anterior or posterior ocular segments. The girl was born at 32 weeks of gestation with a birth weight of $1640 \mathrm{~g}$. Further, her past history revealed congenital hydrocephalus with spontaneous resolution, and her parents were first cousins. Her 32-year-old aunt had similar ocular problems that were undiagnosed. The aunt also had a history of membranous gingivitis and had lost her teeth in the second decade of her life. The patient's first cousin (maternal aunt's 2-month-old boy) also had a history of congenital hydrocephalus.

We excised the conjunctival membranes and administered topical netilmicin preservative-free eye drops (SIFI S.P.A, Italy) 4 times daily, sodium hyaluronate preservative-free eye drops (SIFI S.P.A, Italy) 4 times daily, and dexamethasone ointment (Alcon Couvreur, Belgian) 2 times daily for the first two postoperative days. Serological and microbiological examinations for cytomegalovirus, Epstein-Barr virus, human immunodeficiency virus, rubella virus, Toxoplasma gondii, mycoplasma pneumonia, Chlamydia trachomatis, Treponema pallidum, and Corynebacterium diphtheria were negative. Her blood group was $O$ positive. Histopathological examination of the excised conjunctival membranes exhibited a massive fibrin exudation with a disrupted epithelium, inflammatory cellular infiltration, and moderate leukocyte infiltration (Figure 2), confirming ligneous conjunctivitis.

\footnotetext{
Submitted for publication: November 11, 2014

Accepted for publication: December 8, 2014

Ophthalmology Department, Zekai Tahir Burak Women's Health Education and Research Hospital, Ankara, Turkey.

Biochemistry Department, Zekai Tahir Burak Women's Health Education and Research Hospital, Ankara, Turkey.

Pathology Department, Zekai Tahir Burak Women's Health Education and Research Hospital, Ankara, Turkey.
} 


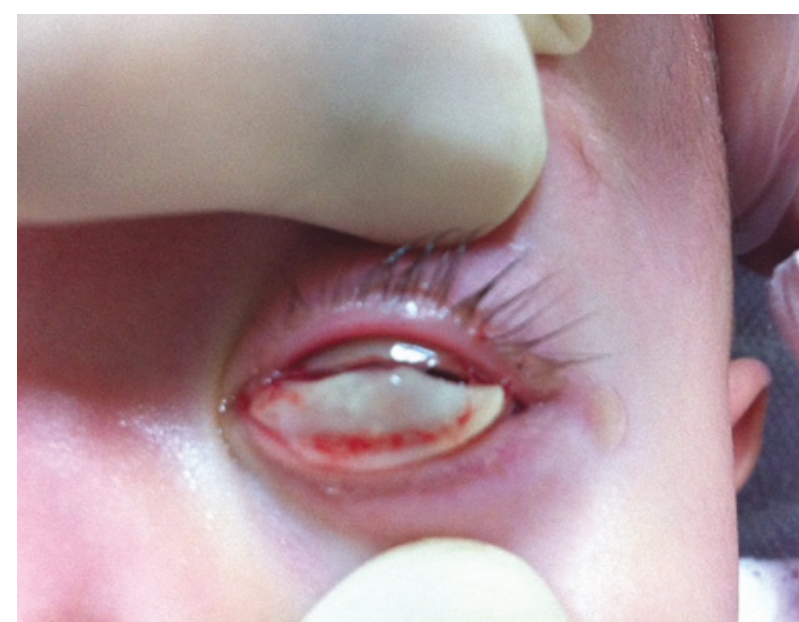

Figure 1. Conjunctival membranes on the lower and upper eyelids in the patient with ligneous conjunctivitis before treatment.

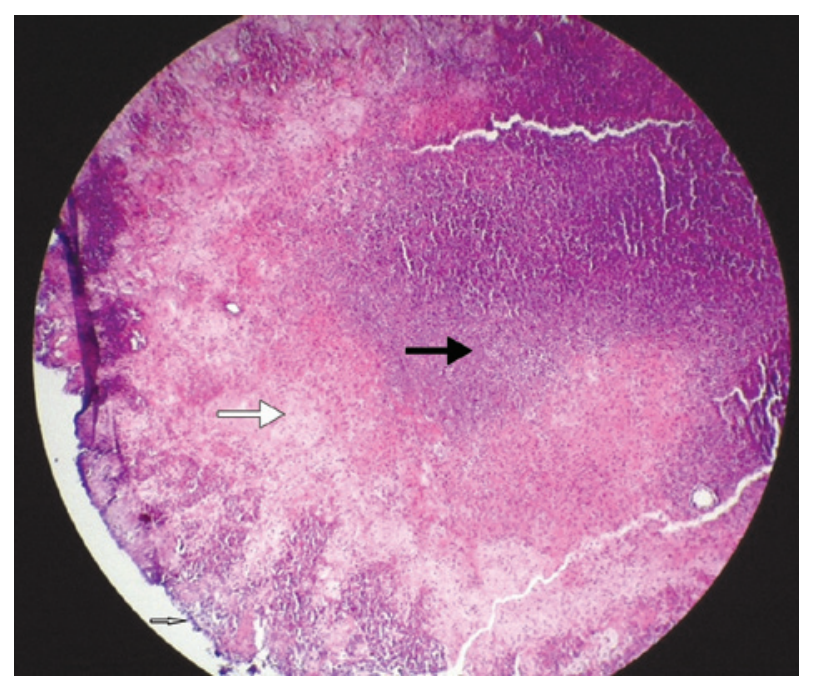

Figure 2. Histopathology of the conjunctival membranes (white arrow: disrup ted epithelium; large white arrow: massive exudation of fibrin; black arrow: inflammatory cellular infiltration).

All clinical signs and her family history indicated plasminogen deficiency. We measured her plasminogen activity at 24\% (normal range, 80\%-120\%); her aunt's and cousin's plasminogen activities were $16 \%$.

We referred the patient to a pediatric hematology clinic, and they did not recommend any systemic treatment. Further, we examined the patient daily and recognized new membrane formation on the lower eyelids on the third postoperative day. We decided to use topical FFP as plasminogen concentrates for use as eye drops are not yet commercially available. We then obtained plasma from a $\mathrm{O}$ negative donor with a normal plasminogen level. Sterile drop bottles with 3-ml plasma were frozen at $-40^{\circ} \mathrm{C}$, and each bottle was thawed for daily use and refrigerated at $4^{\circ} \mathrm{C}$ for $24 \mathrm{~h}$. The topical FFP eye drops were used 6 times daily for 6 weeks; no recurrence was observed during this period. Furthermore, the patient's parents abruptly discontinued the treatment. On the 15th day after the treatment discontinuation, the patient presented to our clinic with bilateral ligneous conjunctivitis. We treated her with topical FFP 6 times daily, netilmicin and collyrium (SIFI S.P.A, Italy) 4 times daily, and topical dexamethasone ointment (Alcon Couvreur, Belgian) 2 times daily for 1 week. The treatment was then continued with only topical FFP 6 times daily. No recurrence was observed during the 3-month follow-up period (Figure 3).
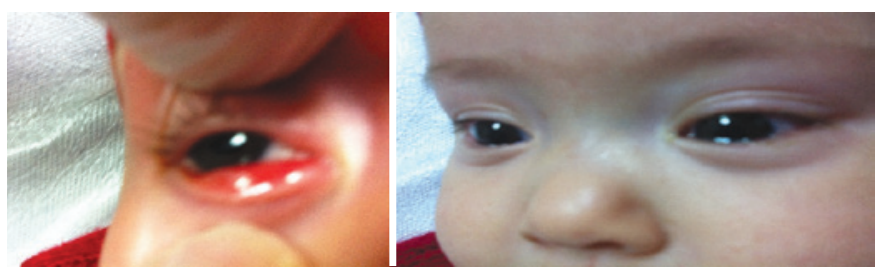

Figure 3. The patient's eyes after treatment.

\section{DISCUSSION}

In this report, we aimed to demonstrate the successful outcome of topical FFP application in an infant with ligneous conjunctivitis; topical FFP without any systemic treatment prevented new or recurrent conjunctival membrane formation after the excision of the conjunctival membranes. Several treatment approaches have been recently reported for treating ligneous conjunctivitis and for preventing the recurrence of the membranes. However, no treatment modality has been accepted ${ }^{(6-9)}$. The treatment regimens generally focus on plasminogen since the etiology of the disease has been clarified, and Schott et al. (1998) have successfully used it ${ }^{(10)}$. Despite studies revealing the efficacy of plasminogen, it is not commercially available.

Tabbara has demonstrated the efficacy of topically and subconjunctivally applied FFP in patients with ligneous conjunctivitis ${ }^{(6)}$. Pergantou et al. and Gürlü et al. have declared that the simultaneous application of systemic and topical FFP was effective in treating ligneous conjunctivitis and preventing recurrences ${ }^{(2,3)}$.

The risks of FFP include hemolysis, infections, transfusion-related acute lung injury, allergic reactions, and anaphylaxis. Systemic treatment also requires hospitalization and intravenous application. Another drawback of FFP is its short half-life ${ }^{(2,3,7,8)}$. To minimize these unwanted effects and difficulties, we decided to use only topical FFP as eye drops in this patient. Our patient showed a good response to topical FFP treatment, and the membranes have not recurred detected while using it.

\section{REFERENCES}

1. Rodríguez-Ares MT, Abdulkader I, Blanco A, Touriño-Peralba R, Ruiz-Ponte C, Vega A, Cameselle-Teijeiro J. Ligneous conjunctivitis: a clinicopathological, immunohistochemical, and genetic study including the treatment of two sisters with multiorgan involvement. Virchows Arch. 2007;451(4):815-21.

2. Gürlü VP, Demir M, Alimgil L, Erda S. Systemic and topical fresh-frozen-plasma treatment in a newborn with ligneous conjunctivitis. Cornea 2008;27(4):501-3.

3. Pergantou H, Likaki D, Fotopulou M, Katsarou O, Xafaki P, Platokouki P. Management of ligneous conjunctivitis in a child with plasminogen deficiency. Eur J Pediatr. 2011; 170(10):1333-6.

4. Azad N, Zafar S, Khan A. Successful treatment of ligneous conjunctivitis with topical cyclosporine and heparin. J AAPOS. 2009;13(5):519-20.

5. Annagür A, Altunhan H, Özbek O, Öztürk BT, Örs R. Congenital hydrocephalus as a rare cause of severe type 1 plasminogen deficiency. Turk Arch Ped. 2013;47:248-50.

6. Tabbara KF. Prevention of ligneous conjunctivitis by topical and subconjunctival fresh frozen plasma. Am J Ophthalmol. 2004;138(2):299-300.

7. Suzuki T, Ikewaki J, Iwata H, Ohashi Y, Ichinose A. The first two Japanese cases of severe type 1 congenital plasminogen deficiency with ligneous conjunctivitis: Successful treatment with direct thrombin inhibitor and fresh plasma. Am J Hematol. 2009;84(6):363-5.

8. Ku JYF, Lichtinger A, Yeung SN, Kim P, Cserti-Gazdewich C, Slomovic AR. Topical fresh frozen plasma and heparin treatment of ligneous conjunctivitis in a Canadian hospital setting. Can J Ophtalmol. 2012;47(5):e27-8.

9. Heidemann DG, Williams GA, Harizer M, Ohanian A, Citron ME. Treatment of ligneous conjunctivitis with topical plasmin and topical plasminogen. Cornea 2003;22(8):760-2.

10. Schott D, Dempfle CE, Beck P, Liermann A, Mohr-Pennert A, Goldner M, Mehlem P, Azuma H, Schuster V, Mingers AM, Schwarz HP, Kramer MD. Therapy with a purified plasminogen concentrate in an infant with ligneous conjunctivitis and homozygous plasminogen deficiency. N Engl J Med. 1998;339(23):1679-86. 